\title{
Farmers' Compliance with Standard Silvicultural Practices and its Impact on the Performance of Pinus Spp. Woodlots in Rubanda District, South-Western Uganda
}

\author{
Byaruhanga Narice $^{1, *}$, Casim Umba Tolo ${ }^{2}$ \\ ${ }^{1}$ Department of Biology, Mbarara University of Science and Technology ${ }^{2}$ Pharm-Biotechnology \\ and Traditional Medicine Centre, Mbarara University of Science and Technology \\ *Corresponding author. @ byaruhanganaricer@gmail.com
}

\begin{abstract}
This study investigated farmers' compliance to standard silvicultural practices and its impacts on the performance of Pinus spp in plantations in Rubanda District, South-western Uganda. A total of 122 pine plantations were randomly selected for intensive assessment. The findings revealed an average spacing of $2.90 \mathrm{~m}$, which significantly differs from the standard spacing of $3.0 \mathrm{~m}$ for pine. Generally, stem density of pine plantations at various age categories such as 8 and 10 years was significantly higher than the recommended. The overall average pruning height of $3.26 \mathrm{~m}$ as practiced by the farmers was significantly lower than $6.81 \mathrm{~m}$, the standard requirement of $50 \%$ average tree height $(\mathrm{p} \leq 0.05)$. In comparison, there were significant differences in average dbh in the three stem density categories. The increase in stem density caused a corresponding decline in dbh of trees in the pine plantations. Farmers with a pine crop of seven years and above with tree stock above the recommended stem density had incurred an average loss of $70.5 \mathrm{~m}^{3}$ per hectare leading to an equivalent financial loss of UGX $3,525,000 /=$ (USD 952.7) per hectare. Therefore, to avoid competition and unnecessary financial loss, adjustment of stem density by thinning as the pine plantation grows is strongly recommended.
\end{abstract}

Keywords: Silvicultural Practices, Pinus Spp, Stem density.

\section{Introduction}

On a global scale, there is a general decline in natural forest cover due to high demand for agricultural land. FAO (2001) reported that during the decade from 1980 to 1990, the world's tropical forests were reduced by an average of 15.4 million hectares per year $(0.8$ percent annual rate of deforestation). The area of land cleared during the decade is equivalent to nearly three times the size of France. Degradation of Uganda's natural forests started in the 1970s (NFA, 2007). In response to this challenge, emphasis has been placed on establishment of forest plantations including pine as supplementary and coping mechanisms. Unfortunately, adoption of pine plantation establishment and management has been done with inappropriate management practices. This has caused a lot of financial loses to many pine tree farmers. 
Silviculture is the art and science of raising trees until they are harvested. Scottish Agricultural College - SAC (2007) warned that pruning is usually beneficial, but if carried out incorrectly it can be detrimental to the health of the tree and to the quality of timber produced. To this effect, no deliberate compliance assessment done at farmer level. ICRAF (1989) noted that the number of trees planted on small-scale farms is increasing in Africa. However, no comprehensive silvicultural assessment has been done on farmland in Rubanda district. In a study of growth performance of 5-year old Pinus caribaea var. hondurensis in selected districts of Uganda, NaFORRI used growth parameters of 5-year-old PCH plantations. The investigated growth parameters were height, diameter at breast height $(\mathrm{DBH})$ and fox tailing in six districts (Kalanzi et al., 2014). The study revealed good growth rates in Gulu and Mubende districts and poor growth rates in Nakasongola District. However, the study did not reveal pine performance under different silvicultural practices. This study investigated pine performance under different spacing and stem densities with a focus on pine farmers' compliance to standard silvicultural practices and performance of Pinus spp in plantations of Rubanda District, South-Western Uganda. This study therefore exposed avoidable mistakes that cause significant losses in pine plantation investments and generated relevant information needed to guide future interventions for improved pine plantation management in the country. The study has revealed facts to all relevant stakeholders and the government that may lead to formulation of policies in regard to deployment and facilitation of forestry extension staff in communities.

\section{Materials and Methods}

\section{Study Area}

The study was conducted in Rubanda District, South-western Uganda (Figure 1). Rubanda District has just been curved from Kabale District. The district comprises of the following SubCounties: Bubare, Nyamweru, Ikumba, Ruhija, Hamurwa, Muko and Bufundi. Hamurwa and Bubare Sub-Counties were purposely investigated because they had a high concentration of pine tree farmers and woodlots. Data was collected from randomly selected parishes. All these parishes had pine plantations. 


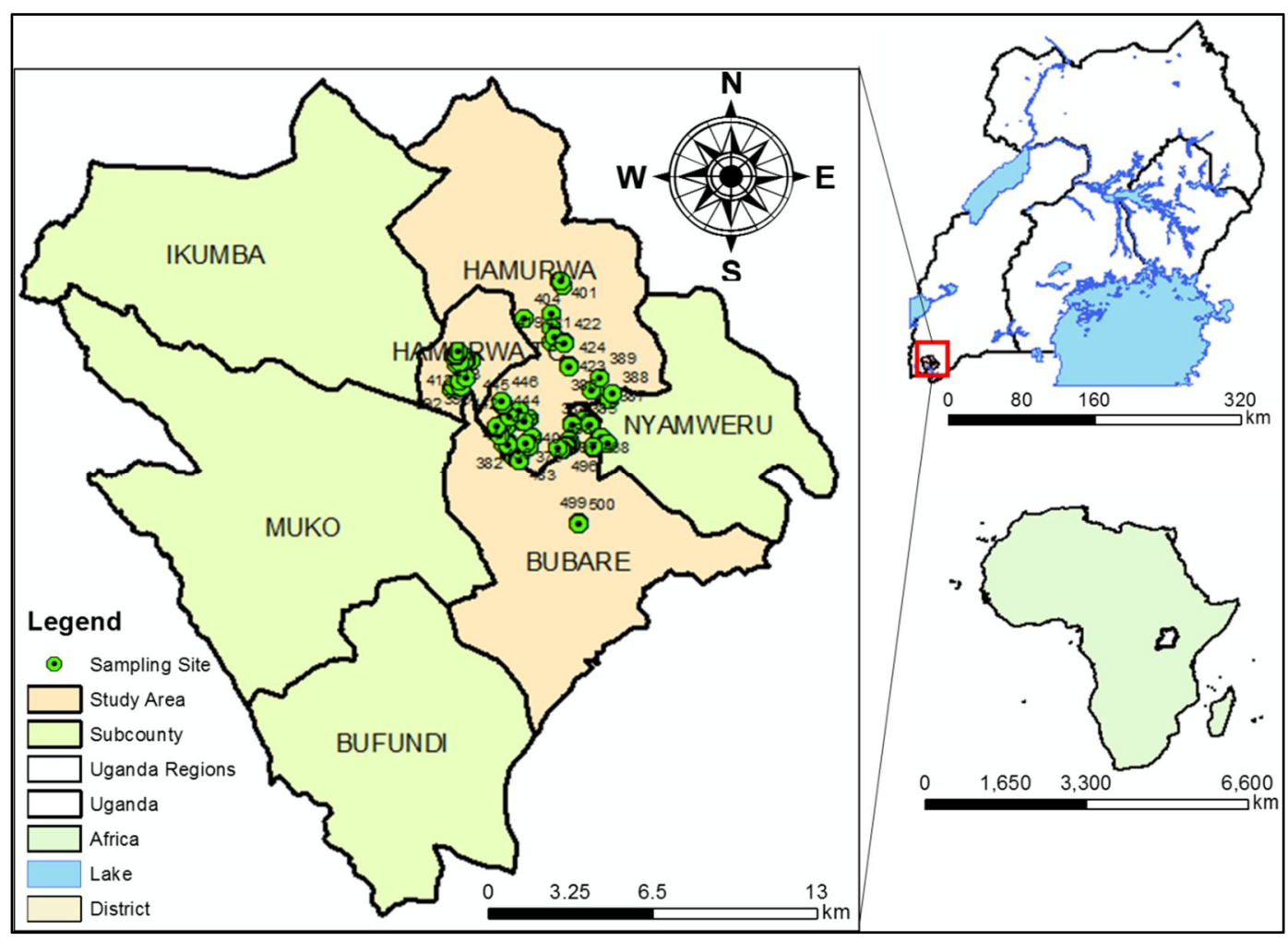

Figure 1. Study Area

\section{Sampling Design}

Multiphase sampling and purposive sampling were employed on this study due to high concentration of pine growers in Hamurwa and Bubare Sub-Counties. In Hamurwa SubCounty, the study parishes were further randomly selected for intensive data collection, and these included: Kakore, Igomanda, Shebeya, and Hamurwa-Karukara Town Council (TC). On the other hand, parishes randomly selected from Bubare Sub-County were: Kashenyi, Kibuzigye, Ihanga, Nyamiyaga and Butobore. In each parish and town council, a sample space was generated from a list of pine tree farmers through interaction with the Local Council Chairpersons. Considering Krejcie and Morgan (1970), a sample size of 122 pine farmers was arrived at from a sampling flame of 170 established pine plantations, using random sampling.

\section{Data Collection Methods}

Practices assessed included spacing, stem density adjustments by thinning, and pruning. These were assessed against the standard management practices recommended by National Forestry Authority (NFA) and Sawlog Production Grant Scheme (SPGS) (Evans, (2009).

\section{Demarcating Plots in forest plantations / woodlots}

In each of the parishes, pine farmers were also randomly selected. In each tree farmer plantation/woodlot, $10 \mathrm{~m}$ x $10 \mathrm{~m}$ square plots were alternately located along the slope. The 
centre location of each demarcated plot was marked and recorded by Geographic Positioning System (GPS). The first plot was at the bottom centre in the plantation, just $20 \mathrm{~m}$ off the boundary so as to avoid edge effect. Pine trees at the age of the plantation get more sun light and their roots feed in the neighbourhood land, the benefits which interior trees cannot get (Bieringer et al., 2013). During assessment, such zone was avoided and was catered for in the $20 \mathrm{~m}$ distance from the plantation edge so as to rule out the edge effect.

In a systematic way, subsequent plots were alternately and purposively set at interval of 30 metres on a transect progressing upwards along the slope. Since conditions across the slope were almost similar, transects were spaced at 100m. This agrees with Kalanzi et al. (2014) as noted that temporally sample plot had been spaced $100 \mathrm{~m}$ apart with emphasis of minimizing age effect. Because of small size, most plantations did not qualify to have more than one transect and thus one transect along the slope was used. A total of 122 plantations were effectively assessed in regard to compliance to standard pine farming practices.

The silvicultural practices' compliance variables measured include: spacing (by linear tape measure), pruning height (by linear measuring tape/hypothometers), length of pruned branch remains - "pegs" (by ruler) and stem density (counting number of trees in the demarcated plots hence determining number of trees per hectare). A hager altimeter was used in measuring tree height.

\section{Pine plantation performance}

In the demarcated plots, determination of pine plantation performance was done by stem diameter assessment and wood volume loss. By use of calliper, diameter at breast height was taken for each individual tree in plots. For consistency, the dbh was taken at $1.3 \mathrm{~m}$ above the ground level on the side of tree facing down slope.

According to Alder et al. (2003), for individual tree volumes calculation, a simple form factor model was used, expressed by the equation:

$\mathrm{v}=$ f.q. $\mathrm{d}^{2} \mathrm{~h}$

Where $v$ is tree volume, $d$ is tree diameter, and $b$ is tree total height $q$ is the constant 0.00007854 (or $\pi / 40000$ ), $f$ is the form factor, or ratio of tree volume to the volume of a cylinder of the same diameter and height. The dbh was used in computing the standing volume of the plantation crop. Frequently, the dbh was used as a guide on the Caribbean Pine Yield Model Workbook for Uganda to determine standing volume yield and volume lose.

\section{Data Analysis}

The data was analysed in regard to mean, standard deviation, variance and median. The Mean was computed to facilitate understanding of the comparison between field data and standardized practices especially indicated in literature. Stem density in context of this research study is the number of trees per unit area. In this case, a unit area is taken as a hectare (ha). One sample t-test was employed as a parametric measure in comparing the pine plating spacing practiced by farmers with the recommended standard spacing. Independent samples t-test was also employed in assessing and comparing impact of various variables on pine performance under different situations. One-Way ANOVA was employed in tree diameter analysis among different stem density categories. Wilcoxon Signed Rank Test was employed in assessment of compliance to the recommended stem density and pruning practices. 


\section{Results and Discussion}

All the 122 pine plantations assessed fell in the altitude between 1837 and 2318 metres above the sea level. The entire plantations assessed had total area of 102ha. The minimum age of the assessed pine crop was 2years while the maximum age was 16 years and the average age was 8.38 years.

\section{Determination of Compliance to Silvicultural Practices of Pine Production Spacing}

The overall average of uncorrected spacing was $2.90 \mathrm{~m}$ as practiced by pine farmers (Table 1$)$.

Table 1. Compliance with standard practices of spacing and thinning

\begin{tabular}{|c|c|c|c|c|c|c|c|c|}
\hline $\begin{array}{l}\text { Management } \\
\text { practice/parameter }\end{array}$ & $\begin{array}{l}\text { Sub- } \\
\text { County }\end{array}$ & $\begin{array}{l}\text { No. } \\
\text { of } \\
\text { trees }\end{array}$ & Min. & Max. & Mean \pm SE & $\begin{array}{l}\text { Std. } \\
\text { Dev. }\end{array}$ & $\begin{array}{l}\text { Required } \\
\text { standard }\end{array}$ & Sig. \\
\hline Uncorrected & Hamurwa & 472 & 1.96 & 3.62 & $2.80 \pm 0.06$ & 0.40 & 3.00 & $0.001 *$ \\
\hline \multirow{2}{*}{ Spacing (m) } & Bubare & 390 & 1.84 & 3.78 & $2.97 \pm 0.05$ & 0.42 & 3.00 & 0.564 \\
\hline & Overall & 862 & 1.84 & 3.78 & $2.90 \pm 0.04$ & 0.42 & 3.00 & $0.010^{*}$ \\
\hline \multirow{3}{*}{$\begin{array}{l}\text { Corrected spacing } \\
\text { (m) }\end{array}$} & Hamurwa & 242 & 1.90 & 3.51 & $2.72 \pm 0.08$ & 0.38 & 3.00 & $0.002 *$ \\
\hline & Bubare & 382 & 1.83 & 3.70 & $2.92 \pm 0.05$ & 0.42 & 3.00 & 0.129 \\
\hline & Overall & 624 & 1.83 & 3.70 & $2.87 \pm 0.04$ & 0.44 & 3.00 & $0.004 *$ \\
\hline \multirow{3}{*}{$\begin{array}{l}\text { Stem density (no. } \\
\text { of stems per ha) at } \\
8 \text { years }\end{array}$} & Hamurwa & 122 & 500 & 1700 & $1124.59 \pm 30.09$ & 332.36 & 600 & $0.000^{*}$ \\
\hline & Bubare & 50 & 400 & 600 & $512.00 \pm 10.93$ & 77.30 & 600 & $0.000 *$ \\
\hline & Overall & 172 & 400 & 1700 & $946.51 \pm 30.28$ & 397.12 & 600 & $0.000 *$ \\
\hline \multirow{3}{*}{$\begin{array}{l}\text { Stem density (no. } \\
\text { of stems per ha) of } \\
\text { pine plantations at } \\
\text { the age of } 10 \text { years }\end{array}$} & Hamurwa & 56 & 600 & 1000 & $825.00 \pm 19.28$ & 144.29 & 300 & $0.000^{*}$ \\
\hline & Bubare & 45 & 400 & 500 & $455.56 \pm 7.49$ & 50.25 & 300 & $0.000^{*}$ \\
\hline & Overall & 101 & 400 & 1000 & $660.40 \pm 21.48$ & 215.91 & 300 & $0.000 *$ \\
\hline \multirow{3}{*}{$\begin{array}{l}\text { Branch remain } \\
\text { ('peg') length left } \\
\text { after pruning }(\mathrm{cm})\end{array}$} & Hamurwa & 302 & 3 & 29 & $11.42 \pm 0.45$ & 7.82 & $1 \mathrm{~cm}$ & $0.000^{*}$ \\
\hline & Bubare & 339 & 2 & 26 & $4.98 \pm 0.225$ & 4.14 & $1 \mathrm{~cm}$ & $0.000^{*}$ \\
\hline & Overall & 641 & 2 & 29 & $8.01 \pm 0.274$ & 6.92 & $1 \mathrm{~cm}$ & 0.000 * \\
\hline
\end{tabular}

* Difference in means significant at 5\% significance level. Note: Corrected spacing considers the slope factor and thus spacing measurement along the slope is corrected by holding the tape measure horizontally (Plate 1). 


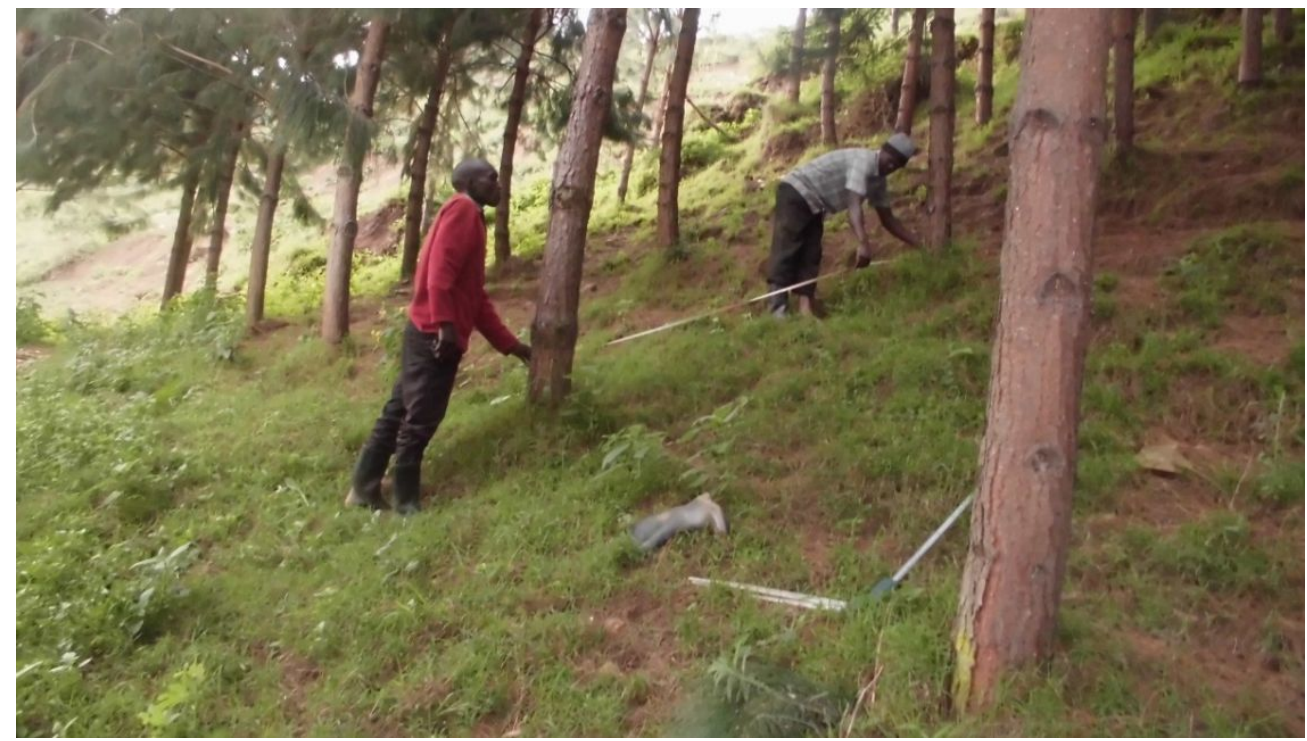

Plate 1 (a). Data collection in Nyaruteija, Kakore Parish in Hamurwa Sub-County

Such is measuring uncorrected spacing since a tape measure is held along the steep slope. Corrected spacing is measured when the upper person fixes the tape measure on the base of the upper tree and the lower person lifts up the tape measure until it is horizontal and then record the distance between the trees. Slope correction is necessary on steep slopes when measuring spacing.

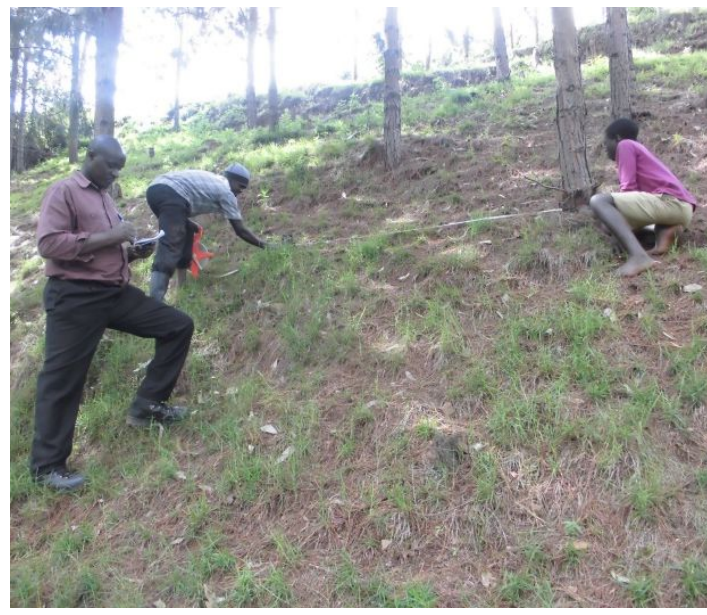

Plate 1 (b). Data collection in Nyaruteija, Kakore

Across the slope, uncorrected spacing was recorded. Slope correction not necessary.

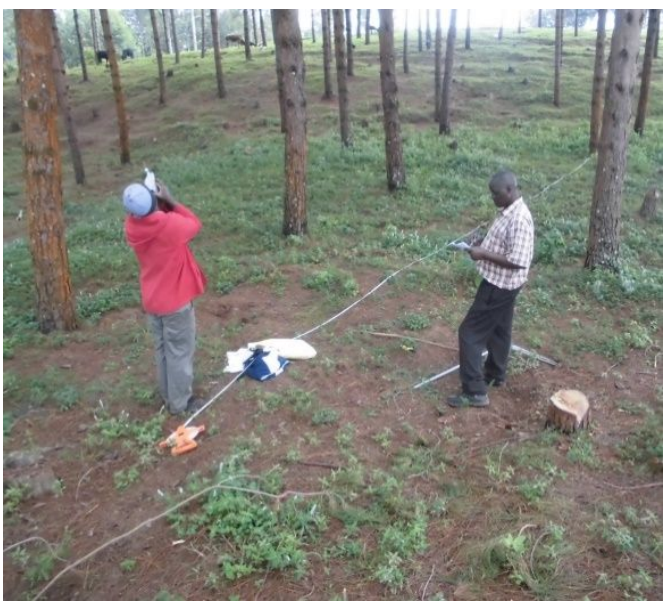

Plate 1 (c). Data collection in Burambo Parish

On a flat terrain, uncorrected spacing was recorded. Slope correction not necessary. 
Uncorrected spacing does not consider slope correction especially on steep terrain areas (Plate 1). Thus farmers hold tape measures along the slope hence affecting the actual horizontal distance between adjacent trees. The opposite is true for the corrected spacing. Corrected spacing considers the slope effect. During marking planting spots, the farmer holds the tape measure horizontally. Similarly, during data collection, tape measures were held horizontally while measuring spacing in plantations on steep areas especially Nyaruteija, Nangaro and Burambira in Hamurwa Sub-County. Corrected spacing is the recommended spacing and ensures uniform spacing in tree plantation establishment. In comparison, the required spacing (standard spacing) was $3.00 \mathrm{~m}$ by $3.00 \mathrm{~m}$. The minimum spacing was $1.84 \mathrm{~m}$ while the maximum spacing was $3.78 \mathrm{~m}$. In comparison, the average of the uncorrected spacing for Hamurwa and Bubare Sub-Counties were $2.80 \mathrm{~m}$ and $2.97 \mathrm{~m}$ respectively. Bubare Sub-County pine farmers had adopted a better spacing close to the recommended of $3.00 \mathrm{~m}$ by $3.00 \mathrm{~m}$. Corrected spacing was also measured especially on steep areas and the overall average was $2.87 \mathrm{~m}$ (Table1). Considering both Hamurwa and Bubare Sub-Counties, the average spacing of $2.90 \mathrm{~m}$ was significantly different from the standard spacing of $3.00 \mathrm{~m}(\mathrm{p} \leq 0.05)$. However, there was no significant difference between the Sub-County spacing $(\mathrm{p}>0.05)$. Considering individual Sub-Counties, Bubare pine spacing did not deviate significantly from the $3 \mathrm{~m}$ standard $(\mathrm{p}>0.05)$. Hamurwa Sub-County significantly deviated from the standard spacing of $3.00 \mathrm{~m}(\mathrm{p} \leq 0.05)$. Pine farmers especially in Hamurwa Sub-County did not comply with standard spacing practice. As noted by Evans (2009), a spacing of $3.00 \mathrm{~m} \times 3.00 \mathrm{~m}$ should be adopted in pine plantation establishment leading to 1111 planted seedlings per hectare. This is recommended for pine plantation establishment for commercial timber production.

\section{Stem Density}

The overall average stem density of 946 stems per ha was practiced by pine farmers in plantations at the 8 years (Table 1 ) which was significantly higher than the standard stem density of 600 stems per ha $(p \leq 0.05)$. Similarly, the overall average stem density of 660 stems per ha was practiced by pine farmers in plantations at the 10 years (Table 1) which was significantly higher than the standard stem density of 300 stems per ha ( $\leq \leq 0.05)$. Hamurwa Sub-County had higher average stem density of 1124 trees per hectare while Bubare Sub-County had lower average stem density of 512 trees per hectare in pine plantations at the age of 8 years. Similarly, Hamurwa Sub-County had higher average stem density of 825 trees per hectare while Bubare Sub-County had lower average stem density of 455 trees per hectare in pine plantations at the age of 10 years. Stem density in pine plantations of 6 years and 9 years old is presented in Figure 2. 


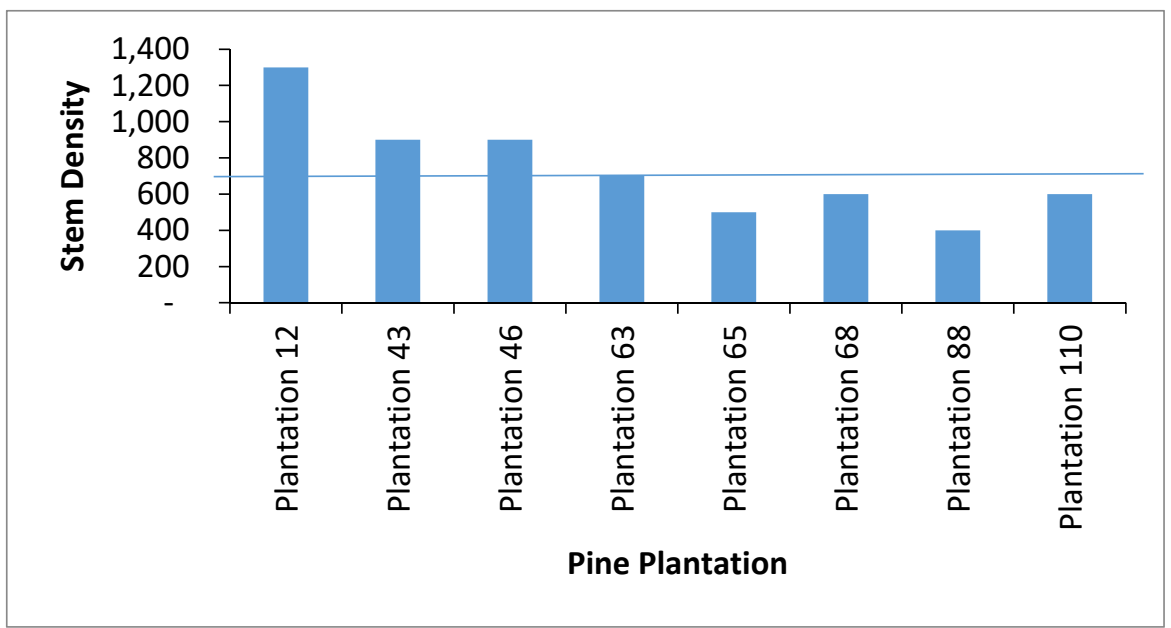

Figure 2(a). Stem density at age of 6 years

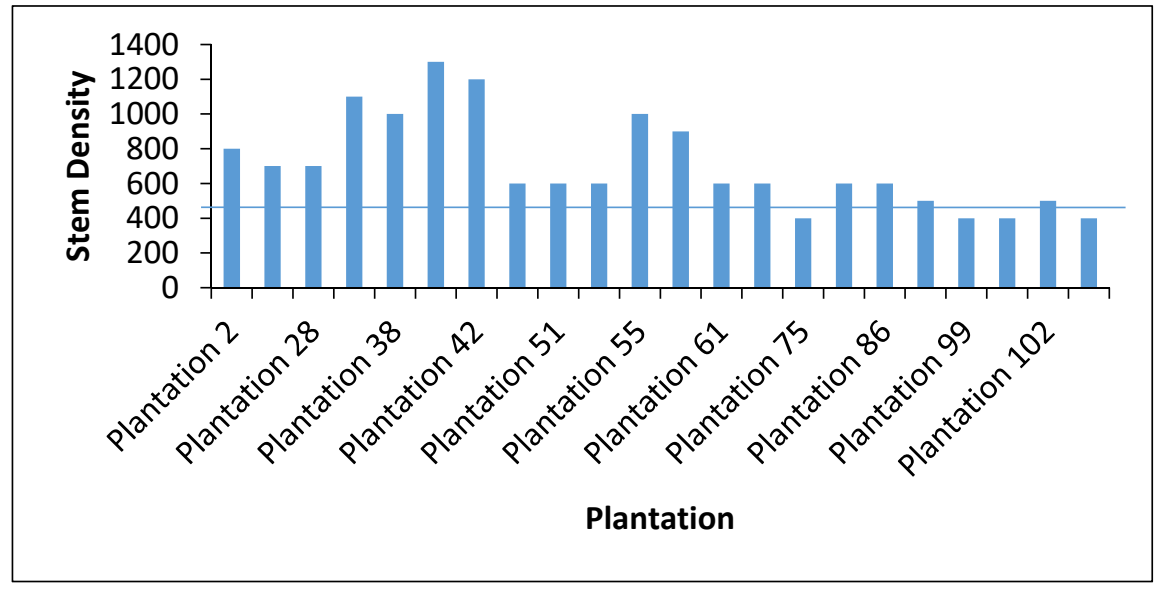

Figure 2(b). Stem Density at 9 years

The horizontal cutline indicates the standard recommended stem density at a given plantation age. It was observed that majority of the pine plantations were overstocked, with high number of pine trees per unit area (hectare) leading to much competition.

In plantations at the age of 6 years, some had the highest stem density of 1300 trees per hectare while others had the least stem density of 400 trees per hectare (Figure 2(a)) with the average of 738 trees per hectare. The required stem density was supposed to be at most 700 stems per hectare. In plantations at the age of 9 years, some had the highest stem density of 1300 trees per hectare while others had the least stem density of 400 trees per hectare (Figure 2(b)) with average of 704 stems per hectare. The required stem density at this age was at most 500 trees per hectare. This was in agreement with Evans (2009) who noted that thinning operations should leave 300 trees per hectare in plantations above 10 years for yield maximization. Texas A and M forest Service (2016) emphasized that in any timber stand, trees compete with each other for light, soil moisture, and nutrients. The more crowded the stand, 
the more intense the competition. In a crowded, overly-dense stand, growth rate is reduced as all trees weaken from the stress. Eventually the weakest trees die. Major effects of high tree density resulting from poor thinning include: Above ground competition especially for light; The trees become slander and thin leading to low timber production; Below ground competition especially for nutrients, water and air; The trees become malnourished leading to low timber production; High root density leading to rotting and poor tree anchorage; and The tree plantation becomes susceptible to wind damage. As a result, plantations with high stem densities were dominated by small saw logs and the timber produced was always little, less dense and small sizes instead of boards that fetch high prices (Plate 2).

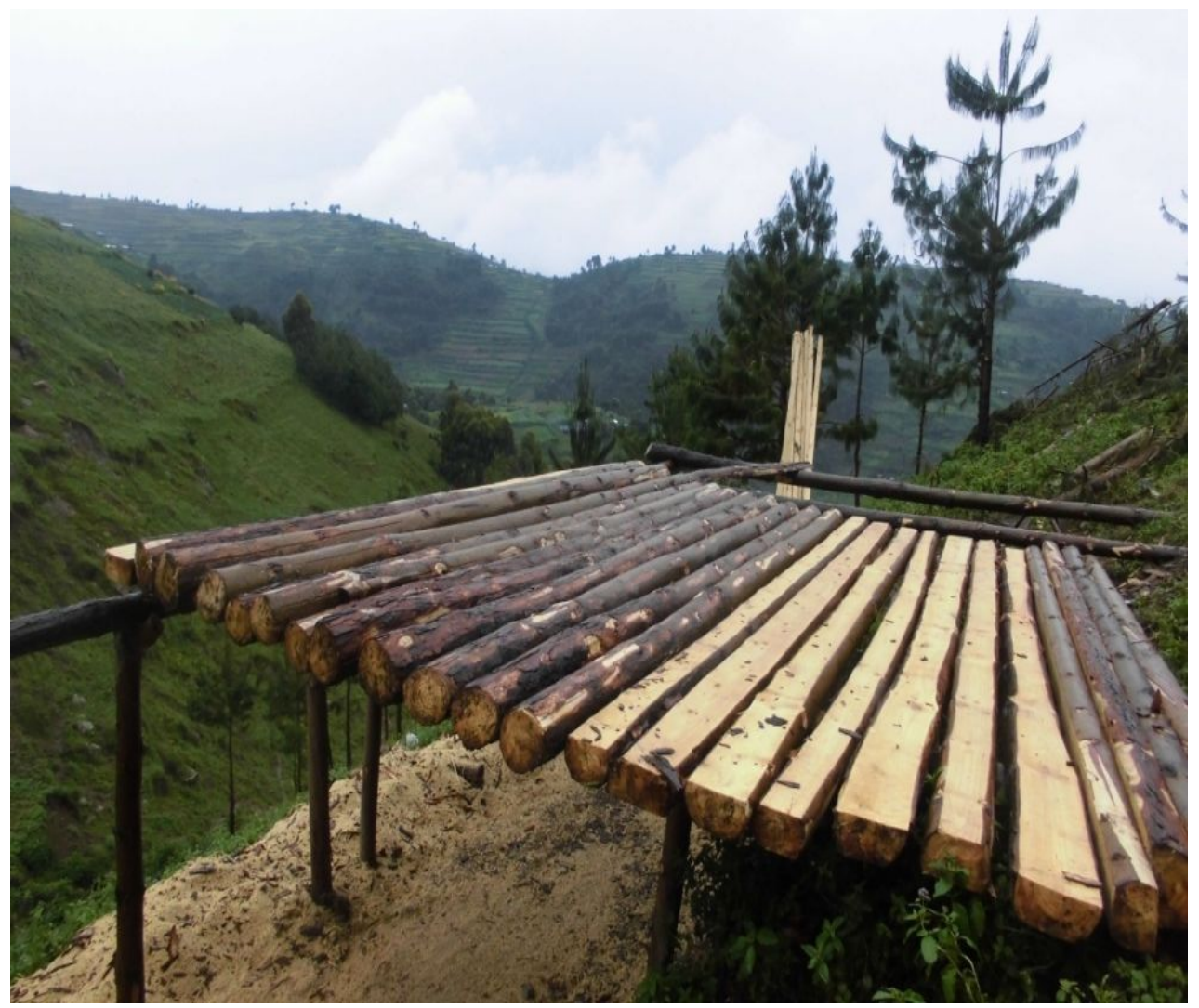

Plate 2. Observed thin logs due to poor thinning and high stem density

\section{Pruning Height}

As a matter of fact, pruning should never exceed $50 \%$ of the tree height. According to observations, generally pruning height did not exceed the recommended height except in a few cases where people cutting branches for bean staking exceeded recommended height. The average pruning height as practiced by pine farmers was $3.08 \mathrm{~m}$ and $3.42 \mathrm{~m}$ for Hamurwa and Bubare Sub-Counties respectively (Table 2) which was significantly lower than the expected $50 \%$ tree height of $6.9 \mathrm{~m}$ and $6.7 \mathrm{~m}$ respectively $(\mathrm{p} \leq 0.05)$. 
Table 2. Farmers' compliance to pruning practices

\begin{tabular}{llllll}
\hline $\begin{array}{l}\text { Sub- } \\
\text { County }\end{array}$ & Pruning practice & $\begin{array}{l}\text { Number of } \\
\text { trees }\end{array}$ & Mean \pm SE & $\begin{array}{l}\text { Std. } \\
\text { Dev. }\end{array}$ & Sig. \\
\hline Hamurwa & Half height (Expected pruning height) & 472 & $6.90 \pm 0.09$ & 1.90 & $0.000^{*}$ \\
& Actual pruning height & 472 & $3,08 \pm 0.08$ & 1.75 & \\
Bubare & Half height (Expected pruning height) & 390 & $6.70 \pm 0.07$ & 1.31 & $0.000^{*}$ \\
& Actual pruning height & 390 & $3.42 \pm 0.10$ & 1.88 & \\
Overall & Half height (Expected pruning height) & 862 & $6.81 \pm 0.06$ & 1.66 & $0.000^{*}$ \\
& Actual pruning height & 862 & $3.26 \pm 0.06$ & 1.85 & \\
\hline
\end{tabular}

According to observations, pruning height was high in Igomanda and Kashenyi parishes and low in Kibuzigye parish. Igomanda and Kashenyi were nearer to Mafuga and Kiriima government pine plantations that demonstrated standard practices than Kibuzigye. Pruning does not contribute significantly to the tree girth but leads to production of knotty free timber. This was in agreement with Víquez et al. (2005) who noted that pruning should be done so as to produce knotty free timber which fetch high prices in market. The Scottish Agricultural College - SAC (2007) emphasized that pruning, coupled with other silvicultural operations, lays a firm foundation to produce a quality crop. The pine farmers did not know the importance of good pruning practices. Farmers also lacked appropriate skills for good pruning practices majorly due to inadequate forestry extension services.

Length of Branch Left after Pruning: It was observed that farmers leave long parts of branch remains ("pegs") when cutting branches in the process of pruning. As a result, long branch remains were observed in pruned pine tree crops (Plate 3).

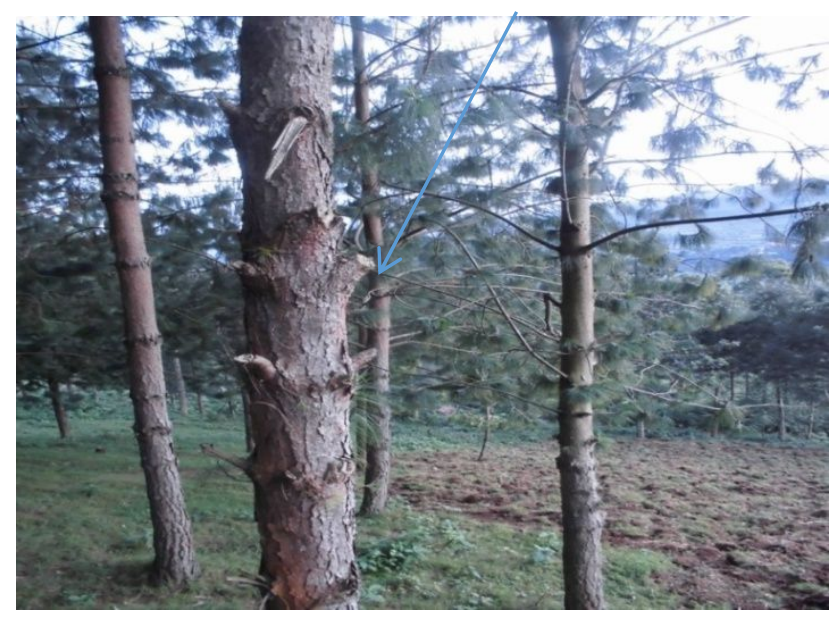

Plate 3. Long 'pegs' after pruning, Nangaro - Hamurwa

According to measurements, branch remain ('peg') length left after pruning for Hamurwa and Bubare Sub-Counties were $11.42 \mathrm{~cm}$ and $4.98 \mathrm{~cm}$ respectively leading to overall average of $8.01 \mathrm{~cm}$ (table 1). The overall average branch length of $8.01 \mathrm{~cm}$ was higher than the recommended $1 \mathrm{~cm}$. The minimum was $2 \mathrm{~cm}$ while the maximum was $29 \mathrm{~cm}$. In terms of pruning, Bubare Sub-County performed better than Hamurwa. The branch remain ('peg') length in Bubare Sub-County pine plantations was significantly lower than that of Hamurwa 
Sub-County plantations ( $\mathrm{p} \leq 0.05)$ using two sample independent t-test. Further still, the overall average of the branch remain ('peg') length of $8.01 \mathrm{~cm}$ in the study area pine plantations was significantly higher than the recommended standard length of $1 \mathrm{~cm}(\mathrm{p} \leq 0.05)$ using one sample Wilcoxon signed rank test. Pine farmers leave long parts of branch ("pegs") when cutting branches in the process of pruning. This was mainly due to ignorance. During pruning, it is advised that branches should be cut as close to the main stem as possible taking care not to injure the stem. At most one centimetre length of branch left after cutting is preferred. Long dead branch remains left after pruning can still be identified in stem tissues after a long time. During timber conversion, the dead branch remains are seen as dead knots which normally fall off creating numerous holes in the timber. These reduce the physical strength and quality of the timber. Determination of Performance of Pinus spp in the Study Area

\section{Effect of Spacing on Pine Performance}

The average dbh of trees with spacing of less than $3.00 \mathrm{~m}$ from each other in the pine plantations was $17.83 \mathrm{~cm}$ while dbh of trees with spacing of $3.00 \mathrm{~m}$ and more was $17.49 \mathrm{~cm}$ (Table 3 ).

Table 3. Performance of Pine Trees as Indicated by dbh in Hamurwa and Bubare Sub-Counties

\begin{tabular}{|c|c|c|c|c|c|c|c|c|}
\hline \multirow{2}{*}{$\begin{array}{l}\text { Sub- } \\
\text { County }\end{array}$} & \multirow[t]{2}{*}{ Characteristic } & \multirow[t]{2}{*}{ Category } & \multirow{2}{*}{$\begin{array}{l}\text { No. of } \\
\text { trees }\end{array}$} & \multicolumn{4}{|c|}{ dbh of trees in the study plots } & \multirow[t]{2}{*}{ Sig. } \\
\hline & & & & Min. & Max. & Mean dbh & Std. dev. & \\
\hline \multirow[t]{2}{*}{ Hamurwa } & Spacing & $<3 \mathrm{~m}$ & 345 & 8.30 & 26.50 & $17.14 \pm 0.18$ & 3.37 & \multirow[t]{6}{*}{0.25} \\
\hline & & $\geq 3 \mathrm{~m}$ & 127 & 8.5 & 28.2 & $16.96 \pm 0.42$ & 4.68 & \\
\hline \multirow[t]{2}{*}{ Bubare } & \multirow[t]{2}{*}{ Spacing } & $<3 \mathrm{~m}$ & 202 & 12.00 & 39.00 & $19.07 \pm 0.31$ & 4.38 & \\
\hline & & $\geq 3 \mathrm{~m}$ & 188 & 10.00 & 31.00 & $17.95 \pm 0.31$ & 4.29 & \\
\hline \multirow[t]{2}{*}{ Overall } & \multirow[t]{2}{*}{ Spacing } & $<3 \mathrm{~m}$ & 547 & 8.30 & 39.00 & $17.83 \pm 0.17$ & 3.89 & \\
\hline & & $\geq 3 \mathrm{~m}$ & 315 & 8.50 & 30.60 & $17.49 \pm 0.25$ & 4.43 & \\
\hline \multirow[t]{3}{*}{ Hamurwa } & \multirow[t]{3}{*}{ Stem density } & $\leq 500$ & 15 & 18 & 28 & $23.47 \pm 0.86$ & 3.31 & \multirow[t]{3}{*}{$0.00 *$} \\
\hline & & $600-1000$ & 268 & 9 & 27 & $17.76 \pm 0.22$ & 3.76 & \\
\hline & & $1100-1700$ & 189 & 8 & 23 & $16.03 \pm 0.23$ & 3.21 & \\
\hline \multirow[t]{3}{*}{ Bubare } & & $\leq 500$ & 206 & 11 & 34 & $19.47 \pm 0.29$ & 4.26 & \\
\hline & & $600-1000$ & 184 & 10 & 39 & $17.48 \pm 0.31$ & 4.26 & \\
\hline & & $1100-1700$ & 0 & 0 & 0 & 0 & 0 & \\
\hline \multirow[t]{3}{*}{ Overall } & & $\leq 500$ & 221 & 11.20 & 34.00 & $19.65 \pm 0.29$ & 4.29 & \multirow[t]{3}{*}{$0.00 *$} \\
\hline & & $600-1000$ & 452 & 8.50 & 39.00 & $17.50 \pm 0.19$ & 3.94 & \\
\hline & & $1100-1700$ & 189 & 8.30 & 22.50 & $15.90 \pm 0.23$ & 3.19 & \\
\hline
\end{tabular}

*Difference in means significant at 5\% significance level.

There was no significant difference in the dbh in the two spacing categories $(p>0.05)$. Pine trees in plantations with less than $3.00 \mathrm{~m}$ spacing, and $3.00 \mathrm{~m}$ and more exhibited almost similar dbh because such spacing cannot impact on the trees when thinning is done early enough. In young crop, the root zone is still small and therefore competition is minimal. At such stage emphasis is put on weed control. This is in agreement with Fox et al. (2007) who found out that herbaceous weed control had a long term impact on pine growth in Southern United States. Thus from planting age (first year) up to six years of age, there was low pine competition especially where wider spacing close to $3.00 \mathrm{~m}$ by $3.00 \mathrm{~m}$ had been adopted. Thus decrease in diameter at breast height could not be easily noticed even in high stem density plantations that 
were still young. This was in agreement with Zhao et al. (2011) that found out that in the first few years after planting, there were no significant effects of management intensity and planting density. In later years, both management intensity and planting density significantly impacted response variables and their interaction was significant for average diameter at breast height (dbh).

\section{Effect of Stem Density on Performance}

In pine plantations with the stem density of 500 trees per ha and below category, the average dbh was $19.5 \mathrm{~cm}$. In a higher stem density category of $600-1,000$ trees per ha, a lower average $\mathrm{dbh}$ of $17.50 \mathrm{~cm}$ was noted. The lowest average dbh of $15.90 \mathrm{~cm}$ was noted in the highest stem density category of more than 1,000 trees per hectare (table 3). The lower the stem density, the higher the dbh and vice versa. Majority of pine trees in Hamurwa Sub-County were in the stem density range of $600-1,000$ trees per ha while majority of pine trees in Bubare Sub-County were in the stem density range of up to 500 trees per ha. Thus majority of trees in Bubare SubCounty had bigger diameters than those in Hamurwa Sub-County. In comparison assessment, there were significant differences among the average dbh in the three stem density categories $(p \leq 0.05)$ using Post Hoc Test. The increase in stem density caused a corresponding decline in $\mathrm{dbh}$ of trees in the pine plantations (Table 3). In comparison, average dbh of Hamurwa and Bubare Sub-Counties were $17.09 \mathrm{~cm}$ and $18.44 \mathrm{~cm}$ respectively. The average dbh of trees in plantations of Bubare Sub-County was significantly higher than that of trees in Hamurwa SubCounty $(\mathrm{p} \leq 0.05)$ using the independent samples $\mathrm{t}$-test. Thus pine performance in Bubare plantations was better than that of Hamurwa plantations.

According to the trend revealed, it was deduced that in such high stocked pine plantations with the age of eight years and above, trees became malnourished and in most cases attained permanent suppression. In appearance, such trees were thin and slender with signs of low timber production. Thus at such year, pine plantations with many trees per hectare, standing volume was lower leading to high potential financial loss on capital investments. According to Evans, (2009), pine plantations by the age of 10 years should have been reduced to 300 stems per hectare.

\section{Volume Loss}

The study revealed that there was a lot of wood volume loss at plantation age of 8 years, 9 years, 10 years and 11 years. According to volume assessment indicated in Table 4, volume loss per hectare was $70.5 \mathrm{~m}^{3}$.

Table 4. Assessment of volume loss in pine plantations in the study area

\begin{tabular}{ccccccc}
\hline S/N & Age & $\begin{array}{c}\text { dbh at low Stem } \\
\text { Density (Cut off } \\
\text { points for higher } \\
\text { dbh) cm }\end{array}$ & $\begin{array}{c}\text { dbh at high Stem } \\
\text { Density (Cut off } \\
\text { points for lower } \\
\text { dbh) cm }\end{array}$ & $\begin{array}{c}\text { Vol. at low Stem } \\
\text { Density (higher } \\
\text { Vol.m3) }\end{array}$ & $\begin{array}{c}\text { Vol. at high } \\
\text { Stem Density } \\
\text { (lower Vol. } \\
\text { m3) }\end{array}$ & $\begin{array}{c}\text { Vol. } \\
\text { Difference } \\
\text { (m3) }\end{array}$ \\
\hline 1 & 8 & 21 & 15 & 139 & 95 & 44 \\
2 & 9 & 23 & 15 & 188 & 95 & 93 \\
3 & 10 & 20 & 16 & 139 & 95 & 44 \\
4 & 11 & 25 & 20 & 240 & 139 & 101 \\
\multicolumn{7}{l}{ Average volume loss per hectare (ha) }
\end{tabular}


For this research study, steep competition was considered from the age of 7 years. Thus every farmer with an overstocked pine crop of seven years and above had incurred a loss of $70.5 \mathrm{~m}^{3}$ per hectare. Since $17 \mathrm{~cm}$ of average dbh in the study area was got, the equivalent standing volume was $240 \mathrm{~m}^{3}$ per hectare (using the Caribbean pine model). Thus $70.5 \mathrm{~m}^{3}$ was $29.38 \%$ of the gross income per hectare expected from the pine plantation. A cubic metre of thinning is normally sold at 50,000/=. In financial terms, the loss per hectare was 3,525,000/= (952.70 US Dollars). This loss had been caused by management mistakes of not respecting recommended thinning schedules as the plantations grew in age. This was mainly due to little interaction with the Forestry Extension Staff, lack of planting guideline copies and lack of pine planting awareness and trainings.

\section{Conclusion and Recommendations}

The research study revealed that average spacing of $2.90 \mathrm{~m} \times 2.90 \mathrm{~m}$ had been adopted. This was different from the recommended standard spacing of $3.00 \mathrm{~m} \times 3.00 \mathrm{~m}$ for timber production. It was observed that majority of the pine plantations were overstocked, with high number of plants per unit area leading to much competition. The findings revealed that farmers had adopted an average higher stem density of 705.74 stems per hectare. Thus pine farmers did not comply with the standard practices. Pine farmers in Bubare Sub-County were more compliant than Hamurwa Sub-County to standard plantation establishment and management standards. Although spacing consideration is important in early plantation establishment especially during lining up, marking, pitting and planting, stem density control is of greater importance in later plantation operations such as pruning as the tree crop advances in age. The pine plantations with many trees per hectare (high stem density), had lower standing volume leading to high potential financial loss on capital investments. Failure to adjust stem density resulted in high pine crop competition that resulted in low volume yield and hence poor performance. The Government and NGOs through extension services should carry out more tree planting campaigns with emphasis on pine plantation establishment and management standards. This will not only bring about diversification in forestry sector but also overcome possibility of future crisis for pine products. Stem density should be strictly adjusted as the pine plantation grows in age to avoid over stocking and competition. This should be through recommended thinning regimes by SPGS and NFA. A technical staff should always be consulted for guidance.

\section{Acknowledgement}

The authors are thankful to the Mbarara University of Science and Technology, specifically the Administration of the Faculty of Science, and that of the Department of Biology for the technical support that enabled design and execution of the study. Special thanks go to the peer review team of Uganda Journal of Agricultural Sciences for the great work done. Finally, we thank Prosy Kyarikunda, Ainobushoborozi Sarah, Byomugabe Justus, Tushabomwe Kenneth and Tubyamureba Eric for providing in kind support and commitment in data collection in hard to reach mountainous areas of Hamurwa and Bubare Sub-Counties, Rubanda district. 


\section{References}

Alder, D., Drichi, P., \& Elungat, D. (2003). Yields of eucalyptus and Caribbean pine in Uganda. Consultancy report. Kampala: Uganda Forest Resources Management and Conservation Programme. https://www.researchgate.net/publication/265934782

Bieringer, G., Zulka, K. P., Milasowszky, N., \& Sauberer, N. (2013). Edge effect of a pine plantation reduces dry grassland invertebrate species richness. Biodiversity and Conservation, 22(10), 2269-2283. https://doi.org/10.1007/s10531-0435-2

Evans, J. (2009). Tree Planting Guidelines for Uganda. Sawlog Production Grant Scheme (SPGS) P. Jacovelli B. Milligan A. Amumpe C. Nalwadda Z. Kakungulu C. Odeke A. Atuyamba T. Businge. The International Forestry Review, 11(4), 541.

FAO (2001). Global Forests Resources Assessment 2000. Main report. FAO Forestry paper 140. Page 130. Rome.

ICRAF (1989). Building on a solid foundation: Achievements, opportunities and impacts. Nairobi, Kenya.

Kalanzi, F., Nansereko, S., Okullo, P., Gwalli, S., Kiyingi, I., \& Guuroh, R. T. (2014).Growth performance of 5-year old Pinuscaribaea var. hondurensis (Barr. and Golf.) in selected districts of Uganda. Uganda Journal of Agricultural Sciences, 15(2), 127 135.https://www.ajol.info/index.php/ujas/article/download/126202/115727

Fox, T. R., Jokela, E. J., \& Allen, H. L. (2007).The development of pine plantation silviculture in the southern United States. Journal of Forestry, 105(7), 337347.http:// rothforestry.com/Resources/Fox\%20et\%20al.\%202007.pdf

NFA (2007).A Gide for Verification of Legal Timber - The Case for Central Forest Reserves in Uganda.

Scottish Agricultural College - SAC (2007).Pruning to Improve Timber Quality. Technical Note 594 1ssNo142.1SBN I85482 858 4. West Mains Road, Edinburgh EH93JG. Support from Scottish Executive Environment and Rural Affairs Department.

Texas A. and M Forest Services (2019). Accessibility, Site Policies and Public Notices.https://tfsweb.tamu.edu/uploadedFiles/TFSMain/Manage_Forest_and_Land/La ndowner_Assistance/Stewardship (1)/Thinning_Pine_Stands.pdf

Víquez, E. \& Pérez, D. 2005.Effect of pruning on tree growth, yield, and wood properties of Tectonagrandis plantations in Costa Rica. Silva Fennica 39(3): 381390.https:// silvafennica.fi/pdf/article375.pdf

Zhao, Kane, Bruce Boders (2011). Growth responses to planting density and management intensity in loblolly pine plantations in the Southern USA lower Coastal Plain Annals of Forest Sciences, Springer Verlag / EDP Sciences, 2011, 63(3) pp. 625-635. 10.1007 /S 1.3595-011.0045-7. Hal-00930786 https://hal.archives-ouvertes.fr/hal00930780/document. 